2021 TheoLogica

An International Journal for Philosophy of Religion and Philosophical Theology

S. I. E. J. LOWE'S METAPHYSICS AND ANALYTIC THEOLOGY

DOI: https://doi.org/10.14428/thl.v5i2.58973

\title{
E. J. Lowe and Divine Causal Agency
}

GREGORY E. GANSSLE

Talbot School of Theology

greg.ganssle@biola.edu

\begin{abstract}
In this essay, I apply Lowe's theory of rational agency to God's causal activity. I argue that Lowe's account fits well the traditional notions that God acts in the world for reasons. In contrast to Lowe's analysis of human causal agency, I argue that in the divine case, reasons for acting are not constituted by needs. They are constituted by God's desires or plans. The fit between Lowe's account of causal agency and the contours of divine causal agency motivate an argument in favor of Lowe's theory. Any philosopher who is a theist ought to think Lowe's account is likely to be true.
\end{abstract}

Keywords: Agency, Reasons, God, Cause, Volition

Traditional theists believe that God is an agent. God brings about effects in the world and does so intentionally. Working out what divine agency amounts to requires an account that is compatible with the kinds of actions God is thought to perform and with the aspects of the divine nature that are most relevant to God's agency. Later medieval philosophers discussed three kinds of causal relations God has with the world (Suarez, 2002). God creates when he brings something into being out of nothing. ${ }^{1}$ God's creation of something is such that there is nothing that previously exists out of which God brings something new. God conserves existing things in being, in that he holds them in existence from moment to moment. Third, God concurs with the causal activity of finite creatures. That is, in every case of a finite object causing something else, God's causal activity is necessary for the production of the effect. Although God is the primary causal agent, created things are secondary causes. As such, they have real causal efficacy. Miracles of intervention, such as God's protecting Daniel's friends in the fiery furnace, were often explained either as God blocking the normal causal activity of the fire or as God refraining from

\footnotetext{
${ }^{1}$ Creation, then, is different than Aristotle's generation. For Aristotle things come to be only out of other things that previously existed. Aristotle, of course, thought the universe was everlastingly old. Plato thought the universe was brought into being by the demiurge, but that it was made out of preexisting matter. See Plato, 2000: 29d-30c.
} 
concurring with the normal causal activity of the fire. ${ }^{2}$ There were, to be sure, differences about how each of these kinds of causal relations were thought to work, but most philosophers thought of divine causation under these three categories. While philosophers today continue to explore divine concurrence and conservation, creation and intervention are the cases most discussed in accounts of divine causal agency.

Within the Christian tradition, there is strong agreement about many aspects of the divine nature. These areas of agreement include the notion that God is the creator of everything outside of himself, that he can do whatever can be done and know whatever can be known. There are, however, some areas of disagreement, such as whether God is metaphysically simple or complex; whether he is temporal or, in some sense, timeless; and whether he knows free actions of creatures ahead of time. Two widely held features that are especially relevant to developing an account of divine causal agency are that God is free in his actions, and he acts for his own reasons.

This essay will proceed in two parts. Part One explores in some detail E. J. Lowe's account of human causal agency as developed in his book, Personal Agency: The Metaphysics of Mind and Action (Lowe, 2008). Part Two investigates how his account may be adapted and appropriated for an account of divine causal agency. Lowe's account of human action is a combination of Agent Causation and Volitionism. That is, a human person is an agent and causes his or her basic actions directly. These actions are not caused by events or by any other means. The agent causes the basic action through a volition or an act of will to perform the action.

\section{Lowe on Agency}

\subsection{Agent and Event Causation}

The development of Lowe's view of human causal agency proceeds in stages. Lowe's first issue concerns whether causes in general should be thought of as events or as agents. The well-established orthodoxy is that all causation is event causation. What he calls "Classical Agency Theory," holds that the category of agent causation should be added to the more common event causation. In contrast, Lowe claims, "[i]n the most fundamental sense of 'cause', only agents are causes - although

\footnotetext{
2 See Daniel, chapter three. This miracle is one of the more common cases in philosophical discussions during this period.
} 
'agents' understood in a very broad sense to include inanimate objects as well as human beings." (Lowe, 2008: 2)

Lowe illustrates this claim by considering what appears to be a straightforward example of event causation. Suppose someone says, "Your collision with the car injured you." Lowe responds, "Here I want to protest that it was the car that injured me, by colliding with me. After all, only the car-not the collision-had the right sorts of properties to cause me injury, being massive, rigid, and fast." (Lowe, 2008: 4) Events are not causes because they are not the right sorts of entities to have causal properties. Only things can be causes. Specifically, substances are causes. For Lowe, an agent "is a persisting object-or 'individual substance' - possessing various properties, including, most importantly, certain causal powers and liabilities" (Lowe, 2008: 122). A substance does not need to be a living thing to count as an agent, in Lowe's sense. Any substance with causal powers is an agent. In order to be $a$ rational agent, however, a substance must be a living thing with consciousness, intentionality and freedom. Only rational agents act for reasons.

Lowe evaluates strategies to reduce agent causation to event causation. One formula for this reduction is as follows:

(I) Agent $A$ caused event $e$ if and only if there was some event, $x$, such that $x$ involved $A$ and $x$ caused $e$. (Lowe, 2008: 123)

This formula seems to fit many cases of causal activity. Suppose Fred turns off the light. Fred caused the light to go off, but he did so by performing another action. He flipped the switch. As a result, there is a flipping of the switch. The flipping of the switch is a good candidate for the event that involves Fred and that causes the light to go off. Using this case, we can read (I) as: "Fred caused the light to turn off if and only if there was some event (flipping the switch), such that flipping the switch involved Fred, and flipping the switch caused the light to turn off." In this case it is the flipping of the switch that is the actual cause of the light going off. While a case like this may appear straightforward, it falls into difficulties. It is difficult, Lowe thinks, to have a precise enough sense of what it means for an event to involve an agent. One way to get at this worry is to question how many agents are "involved" in the flipping of the switch. Certainly, Fred is involved. But the electrician who installed the switch made it possible for that particular light to be turned off with a specific kind of switch-flipping. He, therefore, is also involved. So is the engineer who designed the switch. The use of the concept of being "involved" has to distinguish between those whose involvement is necessary for the effect and those 
whose involvement is also sufficient. In other words, we aim to distinguish between agents that play a real causal role and those that do not.

Fred turning off the light is a case of a non-basic action. That is, it is an action that is accomplished by Fred performing another action; his flipping the switch. Some actions, in contrast, are basic. They are performed directly. They are not performed by performing any other action. Fred turns off the light by flipping the switch. He flips the switch by raising his arm. Fred raises his arm directly. In contrast to those who think of causation in terms of events, Lowe thinks that Fred raising his arm is a basic action. There are many events involved when Fred raises his arm. There are the complex nerve firings and muscle contractions that occur. Although these events are involved in Fred's raising his arm, they are not the cause of his arm going up.

Fred does not raise his arm by causing the firing of his nerves and the contracting of his muscles. Rather, Fred fires nerves and contracts muscles by raising his arm. This scenario is not a case of backwards causation because Fred's raising his arm is not the cause of the nerve firings and muscle contractions. The firings and contractions are caused by the nerves and muscles themselves. The nerves and muscles are contributing causes to the raising of the arm. Each cause in the story is an agent that causes particular effects by some activity. Lowe insists "all that is being claimed is that it is not in virtue of its causation by any events whatever that the agent may be said to cause that event." (Lowe, 2008: 132) In light of such considerations, Lowe claims that the attempts to reduce agent causation to event causation fail.

It turns out, Lowe claims, that event causation is reducible to agent causation. Events are neither eliminated from a thorough analysis of a causal relation, nor do they serve as causes. He proposes the following reduction of event causation:

(II) Event $c$ caused event $e$ if and only if there was some agent, $A$ and some manner of acting $X$, such that $c$ consisted in $A^{\prime}$ s Xing and $A$, by Xing, caused e. (Lowe, 2008: 136)

Lowe considers a typical causal sentence: "The explosion of the bomb caused the collapse of the bridge." To reduce this to a sentence expressing agent rather than event causation, we note the following. Event $c$ is the explosion of the bomb. Event $e$ is the collapsing of the bridge. Agent $A$ is the bomb, and the manner of acting $X$ is exploding. Inserting these terms into (II) gives us,

The explosion of the bomb caused the collapsing of the bridge if and only if there was an agent (the bomb) and some manner of acting (exploding) such that the 
explosion of the bomb consisted in the bomb's exploding, and the bomb, by exploding, caused the bridge to collapse.

In more perspicuous English, "The bomb caused the bridge to collapse by exploding."

Lowe notes that this reduction strategy will fail if we do not distinguish carefully between the action of the agent and the action-result or act (that is, the event that was caused.) The action of the agent is causing the bridge to collapse. The event that is caused in this case is the bridge collapsing. We can see this distinction if we ask what it is that the agent does. The agent causes the bridge to collapse. If we inquire about what is the result of the agent's action, we see that the result is the bridge collapsing. In the case of Fred raising his arm, the action of the agent, is raising his arm. The event that was caused is the rising of his arm. The action-result is not the raising of his arm, but the rising of his arm. The grammar of these phrases indicates that when an arm is raised, it is raised by something. The phrase "a rising of the arm" indicates simply the arm's undergoing the motion. Blurring this distinction may leave us thinking that event $e$ is causing the bridge to collapse rather than the action-result-the bridge collapsing. If we make this confusion, we will think that what the agent causes is the agent causing the bridge to collapse. This analysis leads to a problematic regress.

\subsection{Volitions}

In Lowe's account of agent causation, the agent causes the outcome by acting in a particular way. The bomb causes the bridge to collapse by exploding. In the case of a free agent-one who acts for reasons - there are both parallels with and differences from the inanimate agent case. Lowe writes that when I raise my arm directly, "I still cause my arm to rise by doing something, namely, by willing to raise my arm." (Lowe, 2008: 147) We can see the differences in these cases by noticing that it makes sense to ask what caused the bomb to cause the bridge to collapse. Perhaps the terrorist caused the bomb to collapse the bridge by igniting the fuse. When Fred raises his arm freely to turn off the light, it does not make sense to ask what caused Fred to raise his arm. The free action is not caused at all.

To grasp Lowe's view, it is helpful to contrast it with two other views. On the one hand, it must be contrasted with a fairly common view that a rational agent's actions are caused by her mental states, such as beliefs and desires- or by the onset of these states. On the other hand, it must be contrasted with what Lowe calls Classical Agency Theory. 
The belief-desire position was made famous by Donald Davidson (Davidson, 1980). For Davidson, it is a combination of the agent's relevant beliefs and desires that causes the agent to act. The plausibility of this view rests on two features. First, it rests on the conviction that all causes are events and all events have causes. Thus, the agent's action must be caused by an event. Second, when we wish to identify which events are causes of a rational action, we turn to the experience of the agent. If someone asks Fred why he raised his arm, he is likely to reply that he wanted to turn off the light. We explain our actions by appeal to desires and to our beliefs about how to fulfill them. These two features are captured by Davidson's view.

Lowe argues that the notion that an action is caused by beliefs and desires is problematic. The belief-desire view, as we noted, sees the working of a person solely in terms of event causation. If my beliefs and desires cause me to act, then I do not act in response to reasons. Actions that are caused in this way are not rational or free in a libertarian sense. ${ }^{3}$ The agent does not have control over her action because she is not guided by what she reasonably believes and desires. She is not acting for reasons at all. Lowe comments:

But if we treat those beliefs and desires as causing the motion of his hand, we cannot really say that the agent acts 'for' that reason, because to act 'for' a reason is to be guided by what one (reasonably) believes and desires but not to be caused to behave in a certain way by one's beliefs and desires. (Lowe, 2008: 131)

While rejecting the event-causal belief-desire view, Lowe also rejects classical agency theory. In this family of views, when I perform a basic action, I do so not by doing anything else. One proponent of Classical Agency Theory is Richard Taylor. He argues that "the cause of an act is, quite simply, the agent who performs it." (Taylor, 1966: 66) Taylor describes the volitional theory as one that "simply describes acts as those bodily changes which have volitions as their remote or proximate causes." (Taylor, 1966: 65). Taylor is concerned to remove event-causation from the free and rational actions of human agents. He seems to have a picture in mind that, on a volitionist theory, the agent causes the effect by causing the volition which, in turn, causes the effect. Thus, the effect is not a basic action at all, and the agent is not its direct cause. Since he rejects the claim that all causes are event-causes, he sees no need to appeal to volitions in the explanations of actions.

Taylor raises a further reason to reject the role of volitions:

\footnotetext{
${ }^{3}$ Eric LaRock has pointed out that Hume (and others) would dispute this claim. He thought that the fulfillment of desire makes an action free. Lowe, as a libertarian, thinks that Hume's concept of freedom is inadequate.
} 
No one has ever arrived at a belief in volitions by observing them. They find no place in the data of empirical psychology, nor does it appear that anyone has ever found volitions occurring within himself, or within his mind, by any introspective scrutiny of his mental life. It is doubtful, in fact, whether any such thing as a volition, as construed by this theory, has ever occurred under the sun, and this would seem at least to be a defect in the volitional theory, whatever might be its philosophical merits. (Taylor,1966: 66)

Lowe disagrees with Taylor's claim that it is not possible to find volitions. In fact, he argues that his version of volitionism captures the phenomenology of free actions better than the alternatives:

When I raise my arm, I feel that I am doing something to cause it to rise-something that I could characterize as trying to raise it. I could do this same thing on another occasion and fail to raise my arm - for instance, if my arm were strapped down, or if I were suddenly to be struck with paralysis in my arm. What is this thing that I do? It is a mental act-an exercise of a distinctive mental power of an 'executive' character. The power in question is what philosophers have traditionally called 'the will' and our exercises of that power are our 'volitions' or 'acts of will'. (Lowe, 2008: 172-173)

Lowe's volitionism differs from the kind Taylor rejects. A central difference is that, for Lowe, volitions do not play the role Taylor thinks they do. Taylor thinks volitions are events that must be caused. Lowe argues, in contrast, that volitions are completely uncaused. The will is a power but not a causal power. It is, what Lowe calls, a spontaneous power. There are natural spontaneous powers and rational spontaneous powers. An example of a natural spontaneous power is the power of a radium atom to decay. Its decaying at one moment is not caused. It is entirely spontaneous. There is no specific reason why the atom decays at the moment it does. The volitions of a rational agent are rational spontaneous powers. They are similarly uncaused. These volitions are not simply random events, however. The will is responsive to but not caused by reasons. We can see that volitions are not caused by the agent because they are our most basic actions. I do not cause my will to raise my arm. I simply will to raise my arm. I raise it by willing to do so. In Lowe's words, "Rather than cause his or her own volitions, an agent simply performs, or executes, or enacts them" (Lowe, 2008: 7,8) 


\subsection{Reasons}

Lowe has argued that the free actions of a rational agent are not caused. He insists that this fact does not imply that they are random or inexplicable. Rather, agents act for reasons. The action of an agent is explained by the reasons for which the agent acted.

Lowe is an externalist about reasons. This position holds that reasons are not mental things such as beliefs or desires. Reasons are facts in the world. "A reason for an agent $S$ to perform some action $a$ consists, typically, in some fact concerning the agent's circumstances." (Lowe, 2008: 180) Lowe suggests the example of a person walking down a sidewalk. The fact that a roof slate is falling is a reason for the person to take evasive action. It is the fact in the world and not the agent's beliefs about the roof slate that constitute the reason. It is true that, unless the person knows the slate is falling, she will not act on the reason. The reason itself, according to Lowe, is not her knowledge or belief.

Sometimes a person acts for a reason that turns out not to reflect the way the world is. If I falsely believe a roof slate is sliding off near where I am standing, I will take that to be a reason to jump out of the way. Lowe emphasizes that even in these cases it is not the belief itself that is the reason for my action, but the content of the belief. The content of these beliefs are states of affairs, and states of affairs may or may not obtain. An agent may have a false belief that constitutes a reason for her acting in a certain way.

Reasons serve as explanations for actions, but they are not causal explanations. They are rational explanations. If the person is asked why she jumped, she will say, "The roof slate was falling." That is a perfectly good explanation. It shows her action to be rational. In the case in which she is mistaken about the slate, she will explain her jumping by saying, "I thought the roof slate was falling." This too explains her action and shows it to be rational. After all, if the slate was actually falling, that state of affairs would constitute a good reason to jump out of the way.

Towards the end of Lowe's book, he modifies his position about what serves as reasons for action. He contrasts reasons to believe something with reasons to perform an action. Reasons to believe are facts. Reasons to act belong to a different category. The important difference is that beliefs can be true or false, while actions cannot. Reasons belong to the category of objective need. "Just as the fact that distant ships disappear over the horizon supports the belief that the earth is round so, it might well be said, the need to eat supports the action of sowing corn." (Lowe, 2008: 208) 
The goal of believing is truth, and evidence that some claim is true will always be some fact or set of facts. Truth does not play into the goals for acting, however. Lowe poses the question, "What is it that stands to needs as truth stands to facts?" (Lowe, 2008: 209) The answer is goodness. Goodness in this context is broader than moral goodness, though moral goodness is relevant to moral actions. "Just as a true belief is one that corresponds to fact, so a good action is one which corresponds to need. In another idiom, just as facts are the truth-makers of true beliefs, so needs are the goodness-makers of good actions." (Lowe, 2008: 209)

Lowe's introduction of objective needs in this context is not a strong departure from his earlier claim that reasons to act are facts. Perhaps it is a clarification of this claim. The fact that Texas is home to several species of rattlesnake is not by itself a reason to act. I can entertain that fact while flying over the Pacific Ocean, for example. A fact like this, in a specific situation, however, might inform a need. If I am hiking in Texas and hear a movement in the bush just off the trail next to my leg, the fact about rattlesnakes, together with the need to stay far from them, provides a reason to back away and give the source of the noise a wide berth. It is not the fact itself that constitutes a need. It is the fact plus the relevancy of that fact to my situation that constitutes a need.

\subsection{Summary}

Lowe defends a volitionist agency theory of free human actions. The agent causes the effect by willing to do so, although her willing is not the cause of the effect. Furthermore, her volitions are not themselves caused. Thus, her action is one

performed by her and not caused by things outside of her control. Rational actions are not mysterious, however. They are explained in terms of the reason that agent had for acting, more specifically, the reasons on which the agent acted. This position captures the experience of human agents.

\section{Divine Causal Agency}

In this second part of the essay, I shall apply Lowe's agency theory to divine actions. What is it for God to act? We shall see that Lowe's analysis of rational and free action is suited to divine actions. As I mentioned in the introduction to the essay, there are two parameters a theory of divine agency must engage. These are the kinds of actions that God is thought to perform and the particular features of the divine nature. The two kinds of actions that are most relevant to determining the nature of 
divine agency are his creation of the universe out of nothing and the various actions he performs within the universe.

\subsection{Parting the Red Sea}

Although the theological tradition takes divine action within the universe to include both God's action in accordance with the normal course of events and the kind of intervention that accomplishes something outside the normal course of events, I shall focus on interventions that are miraculous. The case in point will be God's parting of the Red Sea. This event is described in Exodus chapter 14:

Then Moses stretched out his hand over the sea, and all that night the Lord drove the sea back with a strong east wind and turned it into dry land. The waters were divided, and the Israelites went through the sea on dry ground, with a wall of water on their right and on their left. (Exodus 14: 21, 22) ${ }^{4}$

The first thing to note in this account is that God's parting the Red Sea is not described as a basic action. God caused the sea to part by causing the strong east wind to act on the sea. God does perform a direct action, however. He stirs up and points the east wind towards the Red Sea. The action is performed directly by God. He is not caused to initiate the wind to part the sea. He does so freely.

God's ability to perform direct actions in the world is often connected to the idea that God is everywhere. God's omnipresence does not imply that God is literally located or spread out in space. God is omnipresent in that every location in space is subject both to his direct action and his direct knowledge. Richard Swinburne is an example of a philosopher who takes this approach:

I shall understand the claim that God is 'omnipresent' as the claim that he can cause effects at every place directly (as an instrumentally basic action) and knows what is happening at every place without the information coming to him through some causal chain-for example, without needing light rays from a distant place to stimulate his eyes. (Swinburne, 2016: 113)

Although God can perform actions indirectly, as in causing the Red Sea to part as a result of his stirring the east wind, he can act directly. He could have parted the sea without using the wind at all. He could have acted on the water directly.

\footnotetext{
${ }^{4}$ All Scripture references are to the (The Bible: New International Version, 1978).
} 
A second feature of this story to note is that God acts for reasons. In the same chapter, God explains his intended action to Moses:

I will harden the hearts of the Egyptians so that they will go in after them. And I will gain glory through Pharaoh and all his army, through his chariots and his horsemen. The Egyptians will know that I am the Lord when I gain glory through Pharaoh, his chariots and his horsemen. (Exodus 14: 17, 18)

This text indicates that God parted the Red Sea in order to reveal who he is and, thereby, to gain glory from the Egyptians. The broader context of the Exodus narrative includes other reasons that contribute to explaining God's actions. God had called Moses to secure the freedom for the Israelites from their bondage in Egypt. Therefore, his parting the Red Sea can be explained by appeal to his purpose in freeing the Israelites. This specific purpose, in turn, is related to a larger set of intentions about raising up a nation who will serve as God's representatives to the whole world. (See Genesis 12: 1-3)

God's particular action, then, is embedded in a set of reasons. Those reasons that appeal to the specific situation in the world fit well with Lowe's externalism about reasons. In section 3, below, we will turn our attention to how Lowe's account of reasons may need to be adapted to account for the fact that God's reasons for acting are deeply connected with God's own purposes. Before that, we shall turn to creation ex nihilo.

\subsection{Creation ex Nihilo}

Most versions of theism hold that God created the universe ex nihilo. ${ }^{5}$ In the Western traditions the first verse of the Bible sets off this doctrine: "In the beginning God created the heavens and the earth." (Genesis 1:1) The Christian tradition, in particular, includes more precise formulations of the doctrine: "I believe in one God, the Father almighty, maker of heaven and earth, of all things visible and invisible."(Nicene Creed) Thus, God is the only uncreated substance. He brought into being everything else. The emphasis on creation out of nothing highlights that God did not form the world out of pre-existing material, as in some ancient creation stories. (Plato, 2000) There are three relevant implications of the doctrine of creation ex nihilo.

\footnotetext{
${ }^{5}$ Process theism is an exception. There may also be branches of Hinduism that ought to be characterized as theistic, yet do not hold to creation ex nihilo.
} 
The first implication is that the action of God creating the world is a direct action. There were no other substances that God could employ to create the world. Thus, his first action in creating was direct. Even if God created some stuff and then formed the organized universe out of that stuff, the creation of the original stuff was a direct action. As a result, the universe is ontologically dependent on God. But the converse is not true.

The second implication is that God created the world freely. There were certainly no external constraints on his creating. Nothing outside of himself existed the time of creation that could influence or direct his action. Unless he was subject to internal constraints, his creating the universe was done freely. While traditional theology admits that there are some internal constraints on God's actions, these leave a wide variety of options open to God. For example, God's power is thought to extend to everything that is possible. Thus, it is not possible for God to create (or to actualize) a state of affairs that is logically contradictory. God's goodness might constrain him to create a world in which good triumphs over evil. These kinds of constraints do not determine in every detail the specific world God must create. Within the range of universes that are logically consistent and morally sufficient, there are uncountable options. God is free in his choosing among these possibilities.

The third implication is that God creates the world for reasons. That God creates for reasons is not an implication simply of the fact that there is a being who creates. It is possible that there could be a creator who brings something into being without thinking about it. The theistic tradition contains the notion that God creates a specific kind of world that is suited to his plans. This is a world, among other things, that sustains rational creatures who have causal powers to affect the world around them. God's reasons for acting in the case of creation ex nihilo, as in the case of divine intervention, are connected to his purposes concerning the kind of world he wants. In the Biblical tradition, some of these desires are spelled out. For example, God created human beings in his image and gave them a task: "Be fruitful and increase in number; fill the earth and subdue it. Rule over the fish in the sea and the birds in the sky and over every living creature that moves on the ground." (Genesis 1: 28) The task that God gives human beings requires the world to be responsive to human agency. He creates the world with these desires in mind. ${ }^{6}$

\footnotetext{
${ }^{6}$ It is likely that God has plans and desires that shape how he acts in the world and that we know nothing about. The point here is that he has revealed some of his desires to us.
} 


\section{E. J. LOWE AND DIVINE CAUSAL AGENCY}

\subsection{The Nature of Divine Reasons.}

Lowe has argued that the reasons for which human agents act are best thought of as needs. He recognizes that it is not easy to get clear on the nature of a need:

I shall not attempt to answer this difficult question in the present chapter. For my present purposes it suffices to identify needs as items belonging to a distinct ontological category and as having a 'logical shape' which suits them, unlike facts, to constitute reasons for action of an objective kind. (Lowe, 2008: 208)

While he does not specify precisely what a need is, on his account needs are objective. One may be completely unaware of a need one has. In Lowe's story of the roof slate that is falling, "the need to avoid life-threatening injury supports the action of jumping out of the way of a falling slate." (Lowe, 2008: 208) Thus, the objective need provides a good reason for action. Note that the need to avoid a life-threatening injury is what we could call a persistent need. It is persistent because it is general. There are all kinds of life-threatening injuries that should be avoided. A persistent need can become an immediate need for a person when she is in the relevant situation. When the slate is falling over a person's head, her persistent need to avoid injury in general becomes an immediate need to avoid a particular injury. Both immediate and persistent needs that are not immediate, then, can be reasons for acting for human beings. If the slate is falling, the immediate need is a good reason to jump out of the way. If it is my house that has loose roof slates, the persistent need to prevent and avoid life-threatening injury is a good reason to pull out the ladder and make sure the slates are secure. In each case my need is a reason for acting.

A need is connected to a vulnerability or a lack. When the slate is falling, those nearby are vulnerable. They are vulnerable because they lack the ability to be hit by a slate without being injured. They are not vulnerable to a falling snow flake, so the fact that the flake is falling does not give a reason to jump out of the way. Human beings need food because we are vulnerable to starvation. We lack the ability to sustain ourselves without regular nutrition.

When it comes to divine agency, the category of need does not apply. God is completely self-sufficient. He has no lack or vulnerability. He still acts for reasons, however. Both when he intervened in the world, for example, to part the Red Sea, and when he created ex nihilo, the reasons for which he acted are connected to his broader purposes. When he parted the Red Sea, as we saw, his purposes were to display his glory to the Egyptians, to bring the Israelites to the promised land, and to raise up a people through whom all the nations of the world would be blessed. 
These purposes, when combined with the fact that the Egyptian army was approaching, provided the reasons for God to act as he did. The concrete situation plays an essential role in God's reasons for acting. Had the Israelites already entered the promised land, it is possible that God would have had no reason to part the Red Sea. It was the fact that the Israelites were facing the sea and the Egyptian army was closing in that, together with God's purposes, constituted his reasons to act.

At the time God created the world, there was no external situation, analogous to the location of the Israelites and the Egyptians, that contributed to God's reasons for acting. It is possible that God may have foreknown the future state of the world, and these facts might have contributed to his reasons for acting. It also may be that God has middle knowledge. That is, God may have knowledge of what any person would do in any possible situation prior to the creation of those persons. ${ }^{7}$ For example, he may have known that if he creates world-1, Moses will obey his command to raise his arms at the Red Sea. This knowledge might have contributed to guiding him in his choice of worlds. ${ }^{8}$ In these ways facts about what free creatures would do may have played a role in God's reasons for creating.

But it seems more likely that God's reasons to create were largely internal. God had purposes in mind, and these purposes guided his actions. These purposes involved the kind of world God would create and what sorts of creatures would inhabit that world. ${ }^{9}$ The Christian tradition holds that at least part of God's reasons for creating involved the desire to manifest his goodness through having significant relationship with beings outside himself. This purpose informed his creating human beings. If his purposes for creating human beings included having relationship with us, it makes sense that he would create us with relational abilities.

Needs and purposes are analogous in some respects. First, the distinction between immediate and persistent needs has an analogue in the case of purposes. God's immediate purpose in parting the Red Sea was to allow the Israelites to cross safely. This immediate purpose is embedded in his broader, more persistent

7 Since it is probably true that there are no merely possible people, God's middle knowledge would be of what any creaturely essence would do in any situation.

${ }^{8}$ Whether God's simple foreknowledge provides enough information to guide God's choices and whether it is possible for God to know counterfactuals of creaturely freedom are controversial topics. The literature on these questions is immense. Some good places to begin include Beilby and Eddy, 2001; Flint, 1998; Hasker, 1989; and Perszyk, 2011.

${ }^{9}$ God foreknowing that certain people will be alive at some future time is not the same situation as God having the purpose that a certain kind of creature would be created. God's foreknowledge is of actual people. God's purposes are, in this context, more general. While I think God does have foreknowledge of every particular, I think his purposes play a much greater role than the external facts in giving him reason to create. 


\section{E. J. LOWE AND DIVINE CAUSAL AGENCY}

purposes. Second, both needs and purposes can be objective. As Lowe has emphasized, I may have a need of which I am unaware. I also may have a purpose that is not up to me. Some prominent moral theories hold that there is an objective purpose to strive for flourishing or to treat human beings as ends rather than merely as means. ${ }^{10}$ These purposes hold whether or not I acknowledge them. Third, needs and purposes are each oriented towards desired states or outcomes. Needs arise because of a lack of these states, while purposes point towards desired states even as I am fulfilling that purpose. I have an immediate moral purpose to exhibit generosity to people around me. This purpose continues to hold even when I am acting generously. My immediate need for food, in contrast, goes away for a time after I have eaten.

It might be odd to think of God as having desires, as he is thought to be selfsufficient. ${ }^{11}$ Desires seem to be connected to lacks, the way needs are so connected. We can distinguish between need-desires and purpose-desires. Need-desires are a function of lacks or of vulnerabilities. Purpose-desires are not related to lacks. They are related to rationally chosen ends. If God chose his purposes for creating human beings, for example, for good reasons, it makes sense that he desires to see these purposes accomplished.

Thinking about God as a rational agent, then, has opened up a new category for thinking about reasons for action. God's reasons for acting are not grounded in needs. How he acts is grounded in his purposes connected to the present situation. ${ }^{12}$ While human beings often act rationally on the basis of needs, we also act for reasons that are grounded in purposes. Not every reason to act is connected to a lack or a vulnerability.

Lowe's theory of human agency, then, can be applied with minor adjustments to divine agency. We can compare how well his theory can be adapted to God's actions with how well Davidson's and Taylor's theories can be adapted. Davidson's beliefdesire account of human agency will simply not fit the divine case. The claim that God's actions are caused by his beliefs and desires implies that each particular action is caused in this way. As we saw in our discussion of creation ex nihilo, God's actions are subject to internal constraints, such as his moral character. This internal constraint is general, however. God's goodness leaves him with a large range of

\footnotetext{
${ }^{10}$ The emphasis on flourishing and on treating human beings as ends rather than merely as means can be found in the works of Aristotle and Kant respectively. See Aristotle, 1941: 1095a 14-30 and Kant, 1998: 4:429.

${ }^{11}$ I want to thank an anonymous referee for raising this question.

${ }^{12}$ Even in the case of creation ex nihilo, God's purposes are connected to the situation. The situation is that there is no world and there are no creatures that can be the fulfillment of his purposes.
} 
options. Davidson's position, in contrast, leaves no options for God. His beliefs and desires will determine his actions. This theory of divine action is in tension with a crucial feature of God's agency.

Taylor's classical agency theory fits the divine case better than the belief-desire account. On this account, God directly causes his action. Rejecting that all causation is event causation allows God himself to be the cause. Taylor's view is that God causes the effects, but he does not do so in virtue of his doing anything. Specifically, it is not by willing that God acts. God simply acts. As we have seen, Taylor worries that in volitional theories, the agent must cause his willing, and the willing subsequently causes the effect. The weakness in applying Taylor's view to the divine case traces the criticisms Lowe raises to applying his account to human agency. God acts for reasons. Thus, he must do something in response to his purposes and the specific situation at hand. This kind of action seems to require the exercise of an executive function. Given God's purposes and the location of the Israelites and the Egyptian army, for example, God initiates the parting of the Red Sea. It is not simply the general features of the nature of God that cause the sea to part at that time. God parts the sea by willing it to part. Thus, we can see that Lowe offers a more satisfactory account of divine causal agency.

\section{Theism as a Line of Evidence for Lowe's Position}

Lowe's account of what it means for a human being to be a rational agent captures the phenomenology of free action. The details of his view fit well within the theological position that God is a rational agent. If we do not restrict the notion of reasons for acting to the category of needs, we can see this fit more clearly, and this adaptation, in turn, makes better sense of our own place in the world. In this last section, I will reverse the order of our thinking. Rather than working out a view of human rational action and then applying it to God, I shall show how we can begin with God and move into an analysis of human agency. In particular, our reflections on divine agency can form the basis of an argument for the claim that Lowe's approach to human agency is largely the correct approach. These considerations will not be persuasive to those who do not believe in God. I think, however, they ought to be persuasive for those who do.

To be sure human beings are very different from God. We are agents who are embodied and finite. Often, we will to do things and fail. Our ability to act directly on the world is limited to our own bodies. We are vulnerable and have many lacks. Thus, we have need-desires as well as purpose-desires. Apart from these limitations, however, we ought to expect that our agency reflects God's agency to a significant 
degree. We freely act for reasons and we bring about effects in the world that would not occur without our causal activity.

I am not arguing that a theory of human agency like Lowe's is entailed by the contours of the theological tradition. I do think, however, that the theological story provides strong prima facie support for this kind of view of agency. Any philosopher who is a theist ought to think Lowe's account is likely to be true. ${ }^{13}$

\section{Bibliography}

Aristotle. 1941. Nicomachean Ethics. In The Basic Works of Aristotle, edited by Richard McKeon. New York: Random House.

Beilby, James K. and Paul R. Eddy. 2001. Divine Foreknowledge: Four Views. Downers Grove: InterVarsity Press.

The Bible: New International Version, 1978 Grand Rapids: Zondervan.

Davidson, Donald. 1980. "Actions, Reasons, and Causes." In Essays on Actions and Events. Oxford: Clarendon Press, 3-20.

Flint, Thomas. 1998. Divine Providence: The Molinist Account. Ithaca: Cornell University Press.

Hasker, William. 1989. God, Time, and Knowledge. Ithaca: Cornell University Press.

Kant, Immanuel. 1998. Groundwork of the Metaphysics of Morals, edited by Mary Gregor. Cambridge: Cambridge University Press.

Lowe, E. J. 2008. Personal Agency: The Metaphysics of Mind and Action. Oxford: Oxford University Press.

The Nicene Creed. https://www.britannica.com/topic/Nicene-Creed. accessed July 11, 2020.

Perszyk, Ken. 2011. Molinism: The Contemporary Debate. Oxford: Oxford University Press.

Plato. 2000. Timaeus. Translated by Donald J. Zeyl. Indianapolis: Hackett.

Suarez, Francisco S. J. 2002. On Creation, Conservation, and Concurrence: Metaphysical

Disputations 20-22. Translated by Alfred J. Freddoso. South Bend, IN: St. Augustine Press.

Swinburne, Richard. 2016. The Coherence of Theism, Second edition. Oxford:

Clarendon Press. https://doi.org/10.1093/acprof:oso/9780198779698.001.0001.

Taylor, Richard. 1966. Action and Purpose. Englewood Cliffs, NJ: Prentice-Hall.

Published Online: August 24, 2021

${ }^{13}$ I would like to thank Mihretu Guta, Eric LaRock, and two anonymous referees for comments that improved this essay. 